\title{
Pemanfaatan tepung daun kelor (Moringa oleifera Lamk) dengan pretreatment asam dan tepung ikan lele terhadap pemulihan anemia secara in vivo
}

\author{
Utilization of powder kelor leaves (Moringa oleifera Lamk) with acid pretreatments and catfish powder on \\ anemia recovery in vivo
}

Ayutha Wijiindyah ${ }^{1}$, Syaiful Anwar ${ }^{1}$, Sri Hetty Susetyorini ${ }^{1}$

\begin{abstract}
Background: It is estimated more than $50 \%$ of the cases of anemia in the world is caused by iron (Fe) deficiency, it needs alternative sources local food that rarely used but cheap.

Objective: This monofactorial experiment was done to find out whether kelor leaves powder resulted from acid pretreatment and addition of catfish powder can support the recovery of iron deficiency anemia, based on an in vivo study with iron $(\mathrm{Fe})$ and hemoglobin $(\mathrm{Hb})$ measurements.

Methods: The experiment was a trial of anemia recovery by providing 42 wistar rats with no iron-containing feeding for 7 days, then continued for 14 days with either one of six kinds of feeding: standard feeding of AIN-93 M, kelor leaves powder or catfish powder (as control), kelor leaves powder with $0.5 \%$ citric acid pretreatment, kelor leaves powder with $0.5 \%$ citric acid pretreatment and catfish powder (1:1), kelor leaves powder with $0.5 \%$ lime pretreatment, or kelor leaves powder with $0.5 \%$ lime pretreatment and catfish powder (1:1). Criteria of anemia recovery was Fe value $>80 \mu g / d l$ and $H b>10 \mathrm{~g} / \mathrm{dl}$. Statistical analysis was performed by using ANCOVA and LSD test.

Results: The in vivo study showed that feeding rats with kelor leaves powder (respective Fe and Hb value was 101.22 $\mu \mathrm{g} / \mathrm{dl}$ and $11.17 \mu \mathrm{g} / \mathrm{dl}$ ), with $0.5 \%$ citric acid pretreatment (respective $\mathrm{Fe}$ and $\mathrm{Hb}$ value was $90.36 \mu \mathrm{g} / \mathrm{dl}$ and 10.68 $\mu \mathrm{g} / \mathrm{dl}$ ), with $0.5 \%$ lime pretreatment (respective $\mathrm{Fe}$ and $\mathrm{Hb}$ value was $115.51 \mu \mathrm{g} / \mathrm{dl}$ and $12.12 \mu \mathrm{g} / \mathrm{dl}$ ), with $0.5 \%$ lime pretreatment and catfish powder (1:1) (respective Fe and Hb value was $107.29 \mu \mathrm{g} / \mathrm{dl}$ and $11.25 \mu \mathrm{g} / \mathrm{dl}$ ), can be used in anemia recovery.

Conclusion: The best result for anemia recovery was obtained from feeding of kelor powder leaves with $0.5 \%$ lime pretreatment.
\end{abstract}

KEY WORDS: iron deficiency anemia, iron, haemoglobin, acid pretreatment, Moringa oleifera Lamk

\begin{abstract}
ABSTRAK
Latar belakang: Diperkirakan lebih dari 50\% kasus anemia yang terjadi di dunia disebabkan oleh defisiensi zat besi (Fe) sehingga perlu dikaji pangan lokal alternatif sumber Fe dengan harga murah namun jarang dimanfaatkan.

Tujuan: Penelitian eksperimental monofaktorial ini bertujuan untuk mengkaji apakah tepung daun kelor hasil pretreatment asam serta penambahan tepung ikan lele dapat memulihkan anemia defisiensi zat besi berdasarkan pengukuran Fe dan $\mathrm{Hb}$ pada uji in vivo.

Metode: Sebanyak 42 tikus dibuat anemia melalui pakan tanpa zat besi selama 7 hari dan dilanjutkan pakan perlakuan selama 14 hari yang dibagi menjadi 7 kelompok perlakuan, yaitu AIN-93 M; tepung daun kelor dan tepung ikan lele sebagai kontrol; tepung daun kelor hasil pretreatment asam sitrat 0,5\%; tepung daun kelor hasil pretreatment asam sitrat 0,5\% + tepung ikan lele (1:1); tepung daun kelor hasil pretreatment jeruk nipis 0,5\%; tepung daun kelor hasil pretreatment jeruk nipis 0,5\% + tepung ikan lele (1:1). Kriteria pemulihan anemia jika nilai Fe $>80 \mu \mathrm{g} / \mathrm{dl}$ dan $\mathrm{Hb}>10 \mathrm{~g} /$ dl. Analisis statistik dilakukan dengan menggunakan uji ANCOVA dan LSD.

Hasil: Tikus dengan pakan tepung daun kelor kontrol (kadar Fe 101,22 $\mu \mathrm{g} / \mathrm{dl}$ dan Hb 11,17 g/dl); tepung daun kelor hasil pretreatment asam sitrat 0,5\% (kadar Fe 90,36 $\mu \mathrm{g} / \mathrm{dl}$ dan $\mathrm{Hb}$ 10,68 g/dl); pretreatment jeruk nipis 0,5\% (kadar Fe 115,51 $\mu \mathrm{g} / \mathrm{dl}$ dan Hb 12,12 g/dl); serta pretreatment jeruk nipis 0,5\% + tepung ikan lele (1:1) (kadar Fe 107,29 $\mu \mathrm{g} / \mathrm{dl}$ dan Hb 11,25 g/dl) dapat digunakan untuk pemulihan anemia in vivo.

Simpulan: Hasil terbaik pemulihan anemia diperoleh pada tikus dengan pemberian pakan tepung daun kelor hasil pretreatment jeruk nipis 0,5\%.
\end{abstract}

KATA KUNCI: anemia defisiensi zat besi, zat besi, hemoglobin, pretreatment asam, Moringa oleifera Lamk

\footnotetext{
${ }^{1}$ Korespondensi: Program Studi IImu Gizi, Fakultas Kedokteran Universitas Diponegoro, Jl. dr. Sutomo No. 14, Semarang, Jawa Tengah, e-mail: aaayutha@gmail.com
} 


\section{PENDAHULUAN}

Diperkirakan lebih dari $50 \%$ kasus anemia yang terjadi di dunia disebabkan oleh defisiensi zat besi $(\mathrm{Fe})$. Anemia defisiensi zat besi dapat disebabkan oleh beberapa hal, antara lain adanya diit rendah Fe, adanya senyawa penghambat penyerapan Fe di dalam bahan pangan, faktor pengolahan pangan yang tidak tepat, dan availabilitas zat besi makanan yang rendah (1-4).

Guna mengatasi hal tersebut di atas, perlu dikaji pangan lokal alternatif sumber Fe dengan harga murah namun jarang dimanfaatkan. Salah satunya adalah daun kelor (Moringa oleifera Lamk) sebagai sumber Fe $(28,2$ $\mathrm{mg} / 100 \mathrm{~g}$ ) (5-7). Pembuatan tepung daun kelor dilakukan dengan proses pengeringan dan dilakukan penambahan asam karena penyerapan $\mathrm{Fe}$ di dalam tubuh akan lebih mudah dilakukan pada $\mathrm{pH}$ rendah. Di samping itu, kondisi yang asam di dalam tubuh mampu menjaga oksidasi ferrous iron $\left(\mathrm{Fe}^{2+}\right)$ menjadi ferric dan mencegah pengendapan ferric iron $\left(\mathrm{Fe}^{3+}\right)$ (7-9). Penambahan tepung ikan lele merupakan salah satu sumber Fe heme. Zat besi jenis ini mengandung asam amino yang mempunyai peranan penting untuk reduksi $\mathrm{Fe}^{3+}$ dan mampu diserap dalam bentuk $\mathrm{Fe}^{2+}$ guna memfasilitasi penyerapan di dalam usus karena adanya kelompok sulfhydryl serta kandungan sistein dan histidin di dalamnya $(10,11)$. Penelitian ini dilakukan untuk mengkaji pemanfaatan tepung daun kelor hasil pretreatment asam terhadap upaya pemulihan anemia secara in vivo.

\section{BAHAN DAN METODE}

Penelitian ini merupakan penelitian eksperimental laboratorik pada hewan coba tikus (42 ekor). Hewan coba yang digunakan adalah tikus jantan jenis Rattus norvegicus strain wistar dengan berat badan rata-rata 200-300 gram dalam kondisi sehat. Kebutuhan Fe pada tikus yaitu $30 \mathrm{mg} /$ $\mathrm{kg}$ (12). Pengkondisian anemia pada tikus atau disebut dengan masa deplesi, dilakukan dengan cara memberikan pakan berdasarkan American Institute of Nutrition (AIN-93 M) selama 7 hari tanpa menyertakan kandungan Fe sehingga tikus mengalami anemia. Parameter anemia untuk tikus yang digunakan dalam penelitian ini adalah jika kadar hemoglobin $(\mathrm{Hb})$ kurang dari $10 \mathrm{~g} / \mathrm{dl}$ dan kadar Fe kurang dari $80 \mu \mathrm{g} / \mathrm{dl}$. Setelah masa deplesi selesai, dilakukan pengukuran kadar $\mathrm{Hb}$ dan Fe pada semua kelompok dan dilanjutkan dengan pemberian pakan (20 gram sehari) (Gambar 1) (13,14). Pakan perlakuan yaitu pemberian pakan pada tikus dengan macam - macam kriteria pretreatment yang dibagi pada beberapa kelompok dan diberikan dengan cara disonde selama 14 hari (Tabel 1). Pada akhir hari ke-15 masa perlakuan, tikus diambil darahnya sebanyak $1 \mathrm{ml}$ melalui mata (medial canthus sinus orbitalis) untuk dianalisis kadar $\mathrm{Hb}$ dan Fe darah. Pengujian Fe menggunakan metode Nitro-Paps sedangkan kadar $\mathrm{Hb}$ diukur dengan metode cyanmethemoglobin (15)
Tabel 1. Perlakuan untuk masing-masing kelompok

\begin{tabular}{|c|c|}
\hline Kelompok & Pakan perlakuan \\
\hline A & $\begin{array}{l}\text { tikus dengan pemberian pakan standar AIN- } \\
93 \mathrm{M}\end{array}$ \\
\hline B & tikus dengan pemberian tepung daun kelor \\
\hline C & $\begin{array}{l}\text { tikus dengan pemberian tepung daun kelor } \\
\text { hasil pretreatment asam sitrat } 0,5 \%\end{array}$ \\
\hline $\mathrm{D}$ & $\begin{array}{l}\text { tikus dengan pemberian tepung daun kelor } \\
\text { hasil pretreatment asam sitrat } 0,5 \%+\text { tepung } \\
\text { ikan lele dengan perbandingan } 1: 1\end{array}$ \\
\hline$E$ & $\begin{array}{l}\text { tikus dengan pemberian tepung daun kelor } \\
\text { hasil pretreatment asam dari jeruk nipis } 0,5 \%\end{array}$ \\
\hline $\mathrm{F}$ & $\begin{array}{l}\text { tikus dengan pemberian tepung daun kelor } \\
\text { hasil pretreatment asam dari jeruk nipis } 0,5 \%+ \\
\text { tepung ikan lele dengan perbandingan } 1: 1\end{array}$ \\
\hline G & tikus dengan pemberian tepung ikan lele \\
\hline
\end{tabular}

di Laboratorium Pusat Antar Universitas (PAU) Universitas Gadjah Mada Yogyakarta. Hasil kemudian diuji statistik dengan menggunakan Analysis of Covariance (ANCOVA) dan Least Significant Difference (LSD).

\section{HASIL}

Hasil analisis ANCOVA menunjukkan bahwa perlakuan pakan berpengaruh terhadap nilai $\mathrm{Fe}$ dan $\mathrm{Hb}$ akhir $(p=0,00)$. Nilai uji T juga memperlihatkan bahwa terdapat perbedaan nilai $\mathrm{Fe}$ dan $\mathrm{Hb}$ yang bermakna antara masa deplesi dan akhir perlakuan $(p=0,00)$. Perbedaan ini terjadi karena setelah masa deplesi, tikus yang mengalami anemia defisiensi zat besi selanjutnya diberi pakan perlakuan sehingga terjadi peningkatan nilai $\mathrm{Fe}$ dan $\mathrm{Hb}$. Perbedaan nilai $\mathrm{Fe}$ dan $\mathrm{Hb}$ pada saat tikus mengalami anemia (masa deplesi) dan setelah diberi pakan perlakuan pada berbagai kelompok ditunjukkan dengan delta peningkatan $\mathrm{Fe}$ dan $\mathrm{Hb}$ (Tabel 2).

Hasil pengujian memperlihatkan bahwa masa deplesi 7 hari dengan pakan AIN-93 M tanpa zat besi telah mampu membuat tikus kelompok perlakuan mengalami anemia $(\mathrm{Hb}<10 \mathrm{~g} / \mathrm{dl}$ dan $\mathrm{Fe}<80 \mu \mathrm{g} / \mathrm{dl})$. Setelah masa deplesi selesai, dilanjutkan dengan pemberian pakan perlakuan. Pengujian pada nilai Fe akhir menunjukkan nilai tertinggi pada kelompok $E$ yaitu perlakuan pemberian pakan tepung daun kelor hasil pretreatment jeruk nipis $0,5 \%(115,51 \pm 1,01 \mu \mathrm{g} / \mathrm{dl})$, kemudian diikuti kelompok $\mathrm{F}(107,29 \pm 1,01 \mu \mathrm{g} / \mathrm{dl})$, kelompok B $(101,22 \pm 1,04 \mu \mathrm{g} / \mathrm{dl})$, kelompok C $(90,36 \pm 1,05 \mu \mathrm{g} / \mathrm{dl})$, dan kelompok G $(82,04 \pm 1,02 \mu \mathrm{g} / \mathrm{dl})$. Nilai Fe pada kelompok D yaitu perlakuan pakan tepung daun kelor hasil pretreatment asam sitrat $0,5 \%$ + tepung ikan lele $(80,54 \pm 1,01 \mu \mathrm{g} / \mathrm{dl})$ tidak menunjukkan perbedaan bermakna dibandingkan dengan perlakuan pada kelompok $A$ dan $G$. Nilai terendah kadar Fe akhir diperoleh pada kelompok $A$ yaitu kelompok pakan AIN$93 \mathrm{M}(78,11 \pm 1,04 \mu \mathrm{g} / \mathrm{dl})$ (Tabel 2).

Demikian juga dengan hasil pengujian pada nilai $\mathrm{Hb}$ akhir (g/dl) yang menunjukkan bahwa nilai tertinggi 


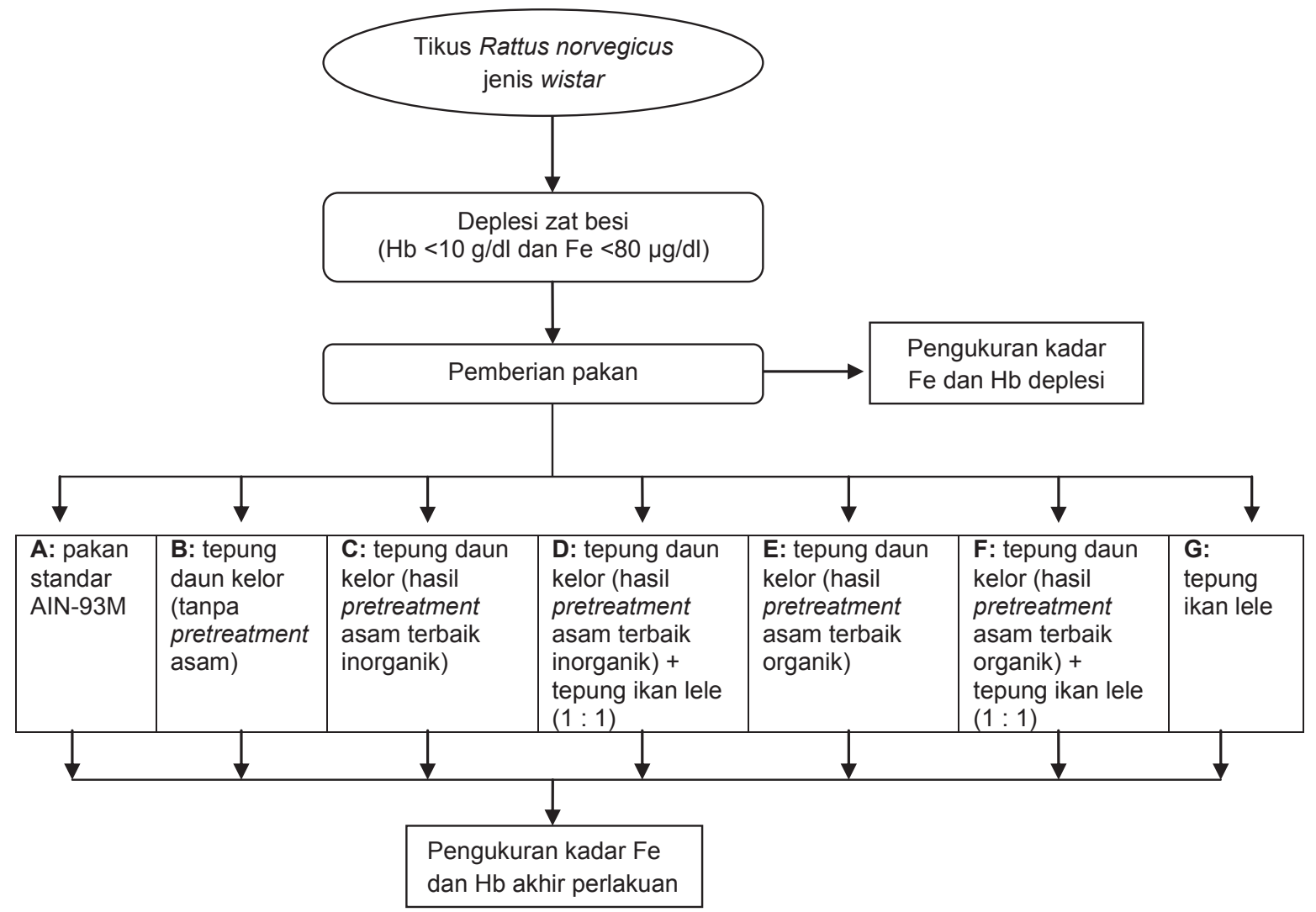

Gambar 1. Alur penelitian in vivo

Tabel 2. Nilai zat besi (Fe) dan hemoglobin ( $\mathrm{Hb})$ tikus wistar masa deplesi dan setelah diberi pakan perlakuan

\begin{tabular}{ccccccc}
\hline \multirow{2}{*}{ Kelompok } & \multicolumn{3}{c}{ Fe $(\boldsymbol{\mu g} / \mathbf{d l})$} & \multicolumn{3}{c}{ Hb $(\mathbf{g} / \mathbf{d l})$} \\
\cline { 2 - 7 } & Masa deplesi & Akhir & Delta & Masa deplesi & Akhir & Delta \\
\hline A & $76,86 \pm 0,38$ & $78,11 \pm 1,04^{\mathrm{f}}$ & $0,67 \pm 0,24^{\mathrm{e}}$ & $9,22 \pm 0,08$ & $9,27 \pm 0,06^{\mathrm{f}}$ & $0,09 \pm 0,05^{\mathrm{f}}$ \\
B & $80,43 \pm 0,71$ & $101,22 \pm 1,04^{\mathrm{c}}$ & $21,43 \pm 0,51^{\mathrm{c}}$ & $9,04 \pm 0,09$ & $11,17 \pm 0,05^{\mathrm{bc}}$ & $2,13 \pm 0,01^{\mathrm{b}}$ \\
C & $76,45 \pm 1,02$ & $90,36 \pm 1,05^{\mathrm{d}}$ & $13,19 \pm 1,19^{\mathrm{d}}$ & $9,02 \pm 0,13$ & $10,68 \pm 0,05^{\mathrm{d}}$ & $1,65 \pm 0,18^{\mathrm{c}}$ \\
D & $79,55 \pm 0,89$ & $80,54 \pm 1,01^{\mathrm{ef}}$ & $1,32 \pm 1,29^{\mathrm{e}}$ & $8,84 \pm 0,10$ & $9,90 \pm 0,05^{\mathrm{e}}$ & $1,07 \pm 0,09^{\mathrm{d}}$ \\
E & $77,87 \pm 1,62$ & $115,51 \pm 1,01^{\mathrm{a}}$ & $37,40 \pm 2,43^{\mathrm{a}}$ & $8,91 \pm 0,09$ & $12,12 \pm 0,05^{\mathrm{a}}$ & $3,21 \pm 0,09^{\mathrm{a}}$ \\
F & $78,99 \pm 0,93$ & $107,29 \pm 1,01^{\mathrm{b}}$ & $28,42 \pm 1,23^{\mathrm{b}}$ & $8,80 \pm 0,14$ & $11,25 \pm 0,05^{\mathrm{b}}$ & $2,45 \pm 0,18^{\mathrm{b}}$ \\
G & $79,83 \pm 2,08$ & $82,04 \pm 1,02^{\mathrm{e}}$ & $2,64 \pm 0,79^{\mathrm{e}}$ & $8,75 \pm 0,08$ & $9,93 \pm 0,05^{\mathrm{f}}$ & $0,56 \pm 0,04^{\mathrm{e}}$ \\
\hline
\end{tabular}

Keterangan :

superskrip yang sama menyatakan tidak ada beda nyata $(p>0,05)$

superskrip yang berbeda menyatakan ada beda nyata $(p<0,05)$

terdapat pada kelompok $E(12,12 \pm 0,05 \mathrm{~g} / \mathrm{dl})$ dan dilanjutkan dengan kelompok $F(11,25 \pm 0,05 \mathrm{~g} / \mathrm{dl})$. Pemberian pakan pada kelompok $B$ yaitu dengan tepung daun kelor kontrol $(11,17 \pm 0,05 \mathrm{~g} / \mathrm{dl})$ tidak menunjukkan perbedaan bermakna dengan kelompok F. Pengujian perbedaan selanjutnya adalah kelompok $A(9,27 \pm 0,06 \mathrm{~g} /$ dl) yang tidak menunjukkan perbedaan bermakna dengan kelompok G (Tabel 2).

\section{BAHASAN}

Berdasarkan hasil penelitian di atas, masa deplesi zat besi selama 7 hari menunjukkan bahwa ukuran sel darah merah kurang dari normal, sintesis $\mathrm{Hb}$ mengalami gangguan, dan sel darah merah yang masih muda akan mengadakan pembelahan sehingga membentuk ukuran sel darah menjadi kecil dan berwarna pucat. Sel tersebut tidak dapat membawa oksigen dari paru-paru ke jaringan serta mempengaruhi jaringan cytochrome $C$, yaitu suatu jaringan yang mengandung protein untuk proses oksidasi dan energi sel. Keadaan ini menyebabkan berkurangnya sirkulasi $\mathrm{Hb}$ dan Fe yang mengandung enzim dan mioglobin yang ditandai dengan rendahnya nilai $\mathrm{Hb}$. Kekurangan $\mathrm{Fe}$ akan mengindikasikan berkurangnya aliran oksigen ke jaringan dan lebih lanjut akan berdampak rendahnya $\mathrm{Hb}$ (16).

Nilai Fe dan $\mathrm{Hb}$ akhir pada tikus dengan pemberian pakan tepung daun kelor kontrol memang mengalami 
kenaikan, meskipun lebih rendah dibandingkan perlakuan pemberian pakan tepung daun kelor hasil pretreatment asam khususnya jeruk nipis $0,5 \%$. Pemberian bahan pangan sumber Fe bisa meningkatkan kadar Fe tetapi peningkatan tersebut tidak lebih dari 20\% apabila tidak ada senyawa yang membantu penyerapan Fe antara lain senyawa asam. Senyawa asam dapat mengurangi senyawa penghambat karena proses perendaman dengan pretreatment asam. Perendaman tersebut menyebabkan hidrolisis yaitu terpecahnya enzim fitase dan terjadi pengurangan asam fitat karena air dapat melarutkan beberapa garam asam fitat dan memecah inositol hexa dan penta phosphate menjadi bentuk yang lebih kecil sehingga tidak berdampak pada penyerapan Fe. Senyawa asam juga akan meningkatkan penyerapan Fe dalam bentuk non-heme dengan cara menambahkan elektron pada $\mathrm{Fe}^{3+}$ sehingga menghasilkan $\mathrm{Fe}^{2+}$ yang lebih mudah untuk diabsorbsi. Selanjutnya, derajat keasaman $(\mathrm{pH})$ yang rendah tersebut dapat menjaga oksidasi $\mathrm{Fe}^{2+}$ menjadi $\mathrm{Fe}^{3+}$ karena kestabilan $\mathrm{Fe}^{2+}$ dibatasi pada $\mathrm{pH}$ sekitar 5 $(3,4,10)$.

Namun, keuntungan lain yang bisa diperoleh tanpa adanya pretreatment asam pada pakan tepung daun kelor kontrol adalah minimnya kehilangan beberapa vitamin dan mineral di dalam daun kelor akibat leaching oleh penambahan senyawa asam. Perendaman juga memberikan efek yaitu reaksi difusi pasif pada watersoluble beberapa mineral sehingga menghilangkan kandungannya akibat larut dalam air. Adanya $\mathrm{pH}$ dapat mengurangi total zat besi, vitamin, dan mineral lain karena konsentrasi asam akan menyebabkan perubahan konsentrasi kelompok karboksil. Hal ini pada akhirnya mempengaruhi nilai Fe dan $\mathrm{Hb}$ akhir pada masa pemulihan karena masing-masing vitamin dan mineral yang mendukung pemulihan anemia zat besi memiliki peran yang berkaitan satu sama lain (8).

Nilai $\mathrm{Fe}$ dan $\mathrm{Hb}$ yang tertinggi diperoleh pada perlakuan dengan pemberian pakan tepung daun kelor hasil pretreatment jeruk nipis 0,5\% karena jeruk nipis sendiri mengandung beberapa senyawa yaitu asam askorbat, asam sitrat, asam malat, dan asam suksinat yang perpaduannya mampu secara efektif membantu penyerapan Fe di dalam tubuh. Persentase terbesar kandungan asam pada jeruk nipis adalah asam sitrat diikuti dengan asam askorbat yang mampu secara individual ataupun bersama-sama melalui mekanisme asam ( $\mathrm{pH}$ mendekati 5) dapat membantu penyerapan Fe. Kandungan asam askorbat pada jeruk nipis secara efektif membantu meningkatkan penyerapan Fe pada bahan pangan dengan bioavailabilitas rendah yaitu bahan pangan jenis non-heme dibandingkan bahan pangan yang bioavailabilitasnya tinggi yaitu bahan pangan heme karena kemampuannya sebagai enhancer yang kuat dalam mereduksi feri menjadi fero (ferro-askorbat). Di samping itu, mereduksi dan menutup pengaruh senyawa penghambat (asam fitat, oksalat, dan polifenol) sehingga penyerapan Fe di dalam tubuh berjalan lebih baik. Pada saat zat besi non-heme memasuki usus, asam askorbat akan berinteraksi dengan senyawa ligand bahan pangan (senyawa $\mathrm{Fe}^{3+}$ ) dan mereduksi penghambatan ligand sehingga menghasilkan ikatan Fe yang lebih basa pada duodenum melalui mekanisme chelate. Adanya kenaikan $\mathrm{pH}$ tersebut kemudian akan dijaga kembali oleh asam askorbat (sifat asam askorbat yang menjaga kestabilan dan larutan kompleks meskipun $\mathrm{pH}$ tinggi) yaitu dengan cara mereduksi bentuk $\mathrm{Fe}^{3+}$ menjadi bentuk $\mathrm{Fe}^{2+}$ dan menjaga timbulnya kembali $\mathrm{Fe}^{3+}$. Asam askorbat akan mengubah $\mathrm{Fe}^{3+}$ menjadi $\mathrm{Fe}^{2+}$ kembali untuk selanjutnya dioksidasi sendiri sehingga menghasilkan $\mathrm{OH}$ dari pembentukan baru $\mathrm{Fe}^{2+}$ dan menjaga pembentukan senyawa $\mathrm{Fe}^{3+}$ yang kurang larut. Mekanisme ini membuat Fe mudah diserap pada duodenum dan usus halus serta penyerapannya meningkat menjadi empat kali lipat $(7,9,17)$.

Jenis asam lain pada jeruk nipis adalah asam sitrat. Asam sitrat memiliki kemampuan mencegah endapan besi yaitu membentuk kompleks dengan ion-ion logam divalent menghasilkan cincin chelate, membentuk senyawa kompleks terlarut di dalam usus halus dan merupakan agen yang cukup kuat untuk meng-chelate dengan ionion penarik elektron yang kuat seperti $\mathrm{Fe}^{3+}$ dalam larutan asam. Kemampuan asam askorbat dan asam sitrat pada jeruk nipis tergantung pada tingkat kematangan serta susunan senyawa pada bahan pangan termasuk senyawa penghambat $(4,9)$.

Pretreatment asam dan proses pengeringan daun kelor selain berpengaruh terhadap nilai Fe, diduga juga mempengaruhi terjadinya penurunan zat-zat gizi lainnya terutama yang terkait dengan pemulihan anemia yaitu vitamin $A, C, E, B_{1}, B_{6}, B_{12}$, dan folat. Pembuatan tepung daun kelor hasil pretreatment asam sitrat 0,5\% memiliki perbedaan dengan tepung daun kelor hasil pretreatment jeruk nipis 0,5\%. Kedua jenis asam tersebut sama-sama memiliki efek leaching pada Fe dan beberapa zat gizi yang berperan terhadap penyerapan Fe. Nilai Fe dan $\mathrm{Hb}$ yang lebih tinggi pada perlakuan dengan pemberian pakan tepung daun kelor hasil pretreatment jeruk nipis 0,5\% dibandingkan dengan pakan tepung daun kelor hasil pretreatment asam sitrat $0,5 \%$ disebabkan oleh hilangnya zat-zat gizi pada tepung daun kelor akibat pretreatment asam yang tergantikan oleh zat gizi yang terkandung dalam jeruk nipis $0,5 \%$. Berbeda dengan pemberian pakan tepung daun kelor hasil pretreatment asam sitrat $0,5 \%$, kondisi asam pada saat perendaman membuat lebih banyak jumlah proton yang terlepas sehingga berpengaruh terhadap ikatan mineral di dalam daun kelor dan menurunkan zat-zat gizi yang ada. Selain itu, asam sitrat tidak memiliki komposisi zat-zat gizi yang dapat mengganti kehilangan zat gizi pada daun kelor. Kadar $\mathrm{pH}$ 
yang asam dapat mempengaruhi struktur senyawa kimia vitamin dan mineral yang selanjutnya akan berpengaruh pada kemampuan kompleks dengan DNA dan aktivitas reaksi enzim. Defisiensi salah satu vitamin dan mineral tersebut akan menyebabkan terganggunya metabolisme Fe di dalam tubuh. Hal inilah yang menyebabkan nilai Fe dan $\mathrm{Hb}$ akhir pada setiap perlakuan berbeda, meskipun sama-sama mendapatkan pretreatment asam tetapi terdapat perbedaan komposisi dari jenis pretreatment-nya. Asam sitrat lebih berperan sebagai penjaga Fe dalam bentuk terlarut, meskipun memiliki kemampuan membuat chelate iron, asam sitrat tidak memiliki kemampuan mereduksi dan terkadang cenderung kurang stabil dan kemampuan meningkatkan penyerapan $\mathrm{Fe}$ relatif lebih rendah. Beberapa asam organik dengan kapasitas pengkelatan kuat (sebagai contoh asam askorbat) lebih efektif dalam pelarutan mineral $(6,9,10)$.

Tingginya nilai $\mathrm{Fe}$ dan $\mathrm{Hb}$ akhir pada perlakuan dengan pemberian pakan tepung daun kelor hasil pretreatment jeruk nipis $0,5 \%$ dibandingkan dengan hasil pretreatment asam sitrat $0,5 \%$ baik dengan penambahan tepung ikan lele atau tidak, terkait dengan jenis senyawa organik yang terkandung dalam jeruk nipis yang dapat mempermudah bioavailabilitasnya dalam tubuh yaitu adanya mekanisme transfer aktif melalui mekanisme transpor asam amino pada sel epitel usus. Pada proses transpor, mineral akan dialirkan dalam bentuk yang sama dengan kebutuhan tubuh dan senyawa chelate dapat diserap dengan sistem transpor asam amino. Hal ini akan menghasilkan peningkatan eritrosit, $\mathrm{Hb}$, perbaikan pankreas, jaringan otot liver, organ pencernaan, dan gastrointestinal mucosa karena terjadinya interaksi antara senyawa organik dengan enzim pada membran. Selain itu, adanya proses sintesa melalui mekanisme senyawa organik dalam menjaga reaksi oksidatif terjadi akibat komponen alami (vitamin A, C, dan E) yang terkandung di dalamnya. Rendahnya bioavailabilitas pada senyawa asam sitrat $0,5 \%$ yang berbentuk inorganik kemungkinan karena adanya sifat yang terkadang antagonis (berlawanan) antara dirinya dengan mineral lainnya. Tak jarang pada bahan inorganik, senyawa yang terkandung di dalamnya dapat menyebabkan reaksi oksidatif $(6,9)$.

Peningkatan nilai $\mathrm{Fe}$ dan $\mathrm{Hb}$ akhir yang lebih kecil pada penambahan tepung ikan lele dibandingkan dengan hasil pretreatment asam dari jeruk nipis, memang berbeda dengan banyak penelitian yang menjelaskan bahwa adanya penambahan asupan bahan pangan dari sumber heme mampu mempercepat penyerapan Fe (15-40\%) dibandingkan zat besi non-heme (1-15\%). Hal ini disebabkan oleh berbedanya proses dan metode pengolahan, proses pengepresan dapat menyebabkan kehilangan beberapa vitamin yang bersifat larut lemak (vitamin A dan vitamin E). Vitamin A berfungsi menjaga Fe agar larut di intestinal lumen serta mencegah hilangnya Fe akibat efek dari asam fitat pada asimilasi Fe sedangkan vitamin E berfungsi menjaga stabilitas membran sel darah merah. Kehilangan jenis vitamin tersebut dapat mempengaruhi ketersediaan Fe di dalam tubuh, yang selanjutnya akan berpengaruh pula pada nilai $\mathrm{Hb}$ yang terbentuk pada tahap akhir $(7,18)$.

Proses pengeringan dalam pembuatan tepung ikan lele menyebabkan dehydration stresser, antara lain terjadinya kerusakan pada komponen asam amino (lisin, sistein, asparagin, dan glutamin) menjadi tidak mudah tercerna dan terserap hingga $18 \%$ dan lebih lanjut akan menyebabkan penurunan sifat fungsional dan nilai biologikal protein serta menyebabkan inaktivasi enzim faktor antinutrisi yang berpengaruh terhadap pencernaan. Sistein memiliki peran yang sangat penting pada penyerapan heme di dalam tubuh karena dapat mengubah $\mathrm{Fe}^{3+}$ menjadi $\mathrm{Fe}^{2+}$, menjaga Fe menjadi larutan kompleks yang mudah untuk diserap, serta menghilangkan oksidasi residu sulfhydryl bebas yang terkandung di dalam meat protein. Bahkan, kandungan sistein dapat meningkatkan penyerapan $\mathrm{Fe}$ dalam bentuk non-heme hingga dua kali lipat, yaitu dengan cara mengikat Fe dengan kelompok thiol. Senyawa lain yang bisa mengalami kerusakan selama pengeringan adalah histidin. Gabungan sistein dan histidin diduga dapat mengikat jaringan Fe sehingga efek pengeringan yang menyebabkan kerusakan dua komponen ini dapat mempengaruhi fungsinya pada penyerapan $\mathrm{Fe}(4,18)$.

Proses pengeringan dapat menyebabkan oksidasi lemak sehingga memicu lebih banyak kehilangan metionin, sistein, dan ikatan disulfida. Lebih lanjut, menyebabkan berkurangnya nilai biologis karena ikatan protein -SSdan aktivitas enzim proteolitik menjadi rendah. Lemak yang teroksidasi menghasilkan produk radikal bebas atau hidroperoksida, yang apabila bereaksi dengan protein akan menyebabkan daya cerna menjadi berkurang karena dapat bereaksi dengan residu lisin sehingga menurunkan fungsi lisin di dalam tubuh (18).

Reaksi lain yang sangat berperan dalam menyebabkan penurunan nilai Fe dan $\mathrm{Hb}$ akhir pada penambahan tepung ikan lele adalah reaksi Maillard. Reaksi ini tergantung dari beberapa parameter antara lain temperatur, water activity (Aw), pH, kelembapan, dan komposisi kimiawi. Reaksi Maillard dapat terjadi sejak suhu pemanasan $37^{\circ} \mathrm{C}$ dan secara umum pencoklatan terjadi pada Aw 0,6-0,85 dan $\mathrm{pH}$ hingga 10. Reaksi ini mengubah residu $L-$ amino acid menjad bentuk $D$-isomers dan formasi yang berhubungan dengan asam amino seperti lysinoalanine (19). Kandungan gula pada ikan lele akan mengalami oksidasi menjadi senyawa karbonil yang memiliki sifat kereaktifan tinggi dan secara langsung bereaksi dengan rantai sisi residu asam amino, termasuk di dalamnya yaitu arginin dan lisin. Reaksi ini akan menghambat beberapa enzim (trypsin, pepsin, carbopeptidase, dan amino peptidase) serta menyebabkan kehilangan beberapa komponen seperti polifenol dan beberapa vitamin (18). 
Reaksi Maillard melibatkan kelompok karbonil dari gula pereduksi dengan asam amino bebas yaitu amino kelompok lisin residu pada protein yang didukung oleh adanya pemanasan dan berlanjut pada terbentuknya basa Schiff. Reaksi ini bersifat tidak stabil, hingga akhirnya tersiklisasi oleh Amadori yang bersifat lebih stabil (rearrangement dan irreversible) dari turunan ketose yaitu $\mathrm{N}$ - yang selanjutnya disubstitusi membentuk senyawa 1-amino-1-deoksi-2 ketosa. Senyawa Amadori dengan senyawa carbonyl terbentuk dari degradasi yang pada akhirnya berdampak pada sifat-sifat bahan pangan. Tahap awal reaksi ini memperlihatkan bahwa secara visual bahan pangan masih berwarna seperti warna aslinya (belum berubah menjadi warna coklat). Namun, kandungan lisin di dalam protein bahan pangan tersebut sudah tidak tersedia lagi secara biologis (bioavailabilitasnya menurun). Semakin lama pemanasan, akan mulai terbentuk aldehyde dari degradasi Strecker pada asam amino yang terkondensasi dengan fragmen gula, furfural, atau dengan produk yang dikeringkan sehingga terbentuk pigmen kecoklatan. Warna coklat yang terbentuk pada produk akhir sering kali diindikasikan sebagai kerusakan kualitas protein yang mengarah pada kehilangan asam amino lisin. Tahap akhir dari reaksi ini adalah terbentuknya pencoklatan polimer nitrogen (melanoidin) yang merupakan kondensasi reaksi furfural atau dehydro reductase. Pada tahap inilah, protein sudah kehilangan sebagian besar zat-zat gizi di dalamnya. Reaksi Maillard menyebabkan bahan pangan susah untuk dicerna karena enzim proteolitik yang terbatas serta pengurangan nilai availability biological dari lisin pada bahan pangan yang mencapai $50 \%$. Hal tersebut juga mengakibatkan pengurangan bioavailabilitas sejumlah mineral yaitu $\mathrm{Fe}$, magnesium, dan kalsium $(8,11,18,19)$.

Pada pencampuran tepung daun kelor pretreatment asam dengan tepung ikan lele, nilai $\mathrm{pH}$ asam pada tepung daun kelor dapat mempengaruhi sifat fisik dan kimia dari protein pada tepung ikan lele dan berdampak pada kemampuan kelarutannya. Adanya proses asam atau basa akan mendegradasi sejumlah protein sehingga menghasilkan perbedaan bentuk dan distribusi molekul di dalamnya $(20,21)$. Selain itu, dimungkinkan ion logam yang ada pada penambahan Fe dari sumber tepung daun kelor pretreatment asam (non-heme) dan Fe dari tepung ikan lele (heme) memiliki sifat yang hampir sama. Pada umumnya, bahan dengan ion logam yang hampir sama sifatnya akan berinteraksi antar ion logam dan saling berikatan dengan protein. Bentuk kompleks tersebut dinyatakan dengan kompleks protonik logam dan menyebabkan mineral sulit larut ketika dicampur di dalam air $(11,18)$.

Nilai terendah $\mathrm{Fe}$ dan $\mathrm{Hb}$ akhir diperoleh pada tikus dengan pemberian pakan AIN-93 M yang tidak menunjukkan perbedaan bermakna dengan pemberian pakan tepung ikan lele. Rendahnya nilai tersebut kemungkinan disebabkan oleh jenis Fe yang ada pada
AIN-93 $\mathrm{M}$ adalah ferric citrate yang hanya mengandung $16,5 \% \mathrm{Fe}$ atau sekitar $6,06 \mathrm{~g} / \mathrm{kg}$. Komposisi ini merupakan jenis $\mathrm{Fe}^{3+}$ sehingga perlu diubah dahulu menjadi bentuk $\mathrm{Fe}^{2+}$ agar dapat diserap baik oleh tubuh. Tanpa adanya senyawa asam, membuatnya lebih sulit larut untuk diserap tubuh $(20,21)$.

\section{SIMPULAN DAN SARAN}

Hasil terbaik berdasarkan kadar Fe diperoleh pada tikus dengan pemberian pakan tepung daun kelor hasil pretreatment jeruk nipis $0,5 \%$ (organik). Selain itu, tikus dengan pemberian pakan tepung daun kelor hasil pretreatment asam yang mampu memulihkan anemia secara in vivo adalah pada pemberian pakan tepung daun kelor kontrol; tepung daun kelor hasil pretreatment asam sitrat $0,5 \%$; pretreatment jeruk nipis $0,5 \%$; serta pretreatment jeruk nipis $0,5 \%$ + tepung ikan lele (1:1).

\section{RUJUKAN}

1. Almatsier. Gizi seimbang dalam daur kehidupan. Jakarta: Gramedia Pustaka Utama; 2011.

2. Arisman. Buku ajar ilmi gizi: gizi dalam daur kehidupan (edisi 2). Jakarta: Penerbit EGC; 2010.

3. Gibney M, Susan LN, Aedin C, Hester HV. Introduction to human nutrition. second edition $2^{\text {nd. }}$ USA: Wiley Blackwell; 2009.

4. Gibson RS. Principles of nutritional assessment. USA: Oxford University; 2005.

5. Katharinia N, Jonni MS, Sitorus M. Cegah malnutrisi dengan kelor. Yogyakarta: Kanisius; 2008.

6. Doerr B, Lindsay C. Moringa leaf powder. USA: ECHO Technical Note; 2005.

7. Hotz C, Gibson RS. Traditional food - processing and preparation practices to enhance the bioavailability of micronutrients in plant - based diets. J Nutr 2007;137(4):1097-100.

8. Wardlaw, Hampl. Perspectives in nutrition. USA: McGraw Hill International Edition; 2007.

9. Williams $\mathrm{P}$, Cloete T. The production and use of citric acid for the removal of potassium from the iron ore concentrate of the Sishen Iron Ore Mine, South Africa. S Afr J Sci 2010;106:1-5.

10. Etchevery P, Hawthorne KM, Liang LK, Abrams SA, Griffin IJ. Effect of beef and soy proteins on the absorption of non-heme iron and inorganic zinc in children. J Am Coll Nutr 2006;25(1):34-40.

11. Miles RD, Jacqueline PJ. Fishmeal in poultry diets: understanding the production of this valuable feed ingredient. USA: Universitas of Florida; 2011.

12. Rodriguez SC, Hotz C, Rivera JA. Bioavailable dietary iron is associated with hemoglobin concentration in Mexican preschool children. J Nutr 2007;137(10):2304-10. 
13. Nakano T, Goto T, Nakaji T, Aoki T. Bioavailability of iron-fortified whey protein concentrate in iron-deficient rats. Asian-Aust J Anim Sci 2007;20(7):1120-6.

14. Rucker R, Storms D. Interspices comparisons of micronutrient requirements: metabolic vs absolute body size. J Nutr 2002;132(10):2999-3000.

15. Tatala S, Ndossi G, Ash D, Mamiro P. Effect of germination on finger millet on nutritional value on foods and effect of food suppelement on nutrition and anemia status in Tanzanian children. Tanzan Health Res Bull 2007;9(2):77-86.

16. Hess CT. Monitoring laboratory values: glucose, hemoglobin, hematocrit, and iron. USA: Lippincott Williams \& Wilkins; 2009.

17. Mahima, Verma AK, Kumar A, Rahal A, Kumar, Roy D. Inorganic versus organic selenium supplementation: a review. Pakistan J Bio Sci 2012;15(9):418-25.
18. Bastos DM, Monaro E, Siguemoto E, Sefora M. Maillard reaction products in processed food : pros and cons. [serial online] 2012 [cited 2012 Feb 22]. Available from: URL: http://www.intechopen.com/ books/food-industrial-processes-methods-andequipment

19. Debnath S. Clarias batrachus, the medical fish: an excellent candidate for aquaculture \& employment generation. Singapore: International Conference in Asia Agriculture and Animal; 2011.

20. Songklanakarin. Effect of acid and alkaline solubilition on the properties of surimi based film. J Sci Technol 2005;27(3):563-74.

21. Womeni HM, Tiencheu B, Linder M, Nabayo EMC, Tenyang N, Mbiapo FT, Villeneuve P, Fanni J, Parmentier M. Nutritional value and effect of cooking, drying, and storage process on some functional properties of rhychophorus phoenicis. Intr J Life Sci \& Pharma Resch 2012;2(3):203-19 